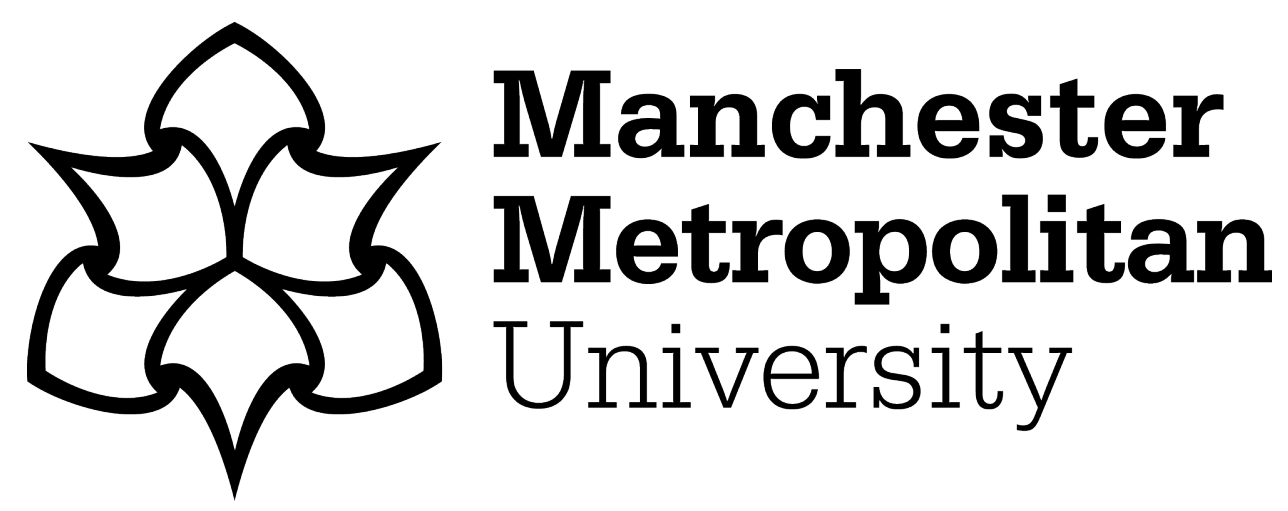

Kamal, Ernawati Mustafa, Lou, Eric CW, Yusof, Nor'Aini and Osmadi, Atasya (2022) Absorptive capacity of Malaysian SME construction organisations. Architectural Engineering and Design Management, 18 (3). pp. 313-324. ISSN 1745-2007

Downloaded from: https://e-space.mmu.ac.uk/627289/

Version: Accepted Version

Publisher: Taylor \& Francis

DOI: https://doi.org/10.1080/17452007.2021.1883518

Please cite the published version 


\title{
Absorptive Capacity of Malaysian SME Construction Organisations
}

Ernawati Mustafa Kamal ${ }^{\star 1}$, Eric C.W. Lou ${ }^{2}$, Nor'Aini Yusof ${ }^{1}$, Atasya Osmadi ${ }^{1}$

1 School of Housing, Building and Planning, Universiti Sains Malaysia, Penang, Malaysia.

2 Department of Engineering, John Dalton Building, Manchester Metropolitan

University, United Kingdom.

${ }^{* 1}$ Corresponding author

Email: ernamustafa@usm.my

${ }^{2}$ Eric C.W. Lou

Email: E.Lou@mmu.ac.uk

${ }^{1}$ Nor'Aini Yusof

Email:ynoraini@usm.my

${ }^{1}$ Atasya Osmadi

Email: $\underline{\text { a.osmadi@usm.my }}$

\begin{abstract}
Absorptive capacity has been acknowledged as a critical component for organisations to sustain, compete and excel in the marketplace. With the current volatile environment, there are increased demand for new knowledge, skills and implementation of new technologies. Every organisation must have the ability to be able to absorb and leverage from new technologies. This research aims to identify the absorptive capacity of Malaysian small and medium enterprise (SME) construction organisations. The research design adapted was based on qualitative approach. 12 semi-structured interviews were conducted with SMEs operating in six different states in Malaysia. Data was analysed using NVivo 12 Pro software and thematic approach was used to categorize the data. This research found 29 main indicators of how construction SMEs develop their absorptive capacity and 10 factors influenced their absorptive capacity. Owners and employees with higher education background and with more industry experience tend to be more receptive to absorb new knowledge. In addition, human resource departments and formal office communications were found
\end{abstract}


to have positive impacts on SMEs absorptive capacity. Suppliers and manufacturers were also identified as important external factors. This research provides clear indicators of how SME construction organisations can develop their absorptive capacity and further improve their productivity. It also provides indication for Construction Industry Development Board on how they can assist the SME construction organisations to absorb and apply new technology in construction processes.

\section{Keywords}

Absorptive capacity

Construction industry

Determinants criteria

Malaysia

Small and medium enterprise

\section{Introduction}

Small and medium-sized enterprises (SMEs) are important catalyst for the Malaysian economy as they represent $98.5 \%$ of the number of businesses in the country (SMECorp, 2020) - contributing $38.3 \%$ of overall GDP, $17.3 \%$ of total exports and $66.2 \%$ of total employment in 2018 (DoSM, 2020). The construction industry (Cl) is also an important part of Malaysian economy. The $\mathrm{Cl}$ supports the national economy through its forward and backward linkages with other industries of economy, such as on-site construction, professional services, manufacturing of materials and equipment, education and training, and the wider supply chain. Collectively, the Malaysian $\mathrm{Cl}$ consists of $90 \%$ SMEs, with large numbers of professional organisations, such as architects, engineers and quantity surveyors as sole proprietors or small organisations (CIDB, 2016). In comparison to other industries (eg. manufacturing and services), the contribution of the $\mathrm{Cl}$ to total national GDP is relatively small, providing $4.2 \%$ in 2019 (BNM, 2020). This is in line with the low productivity levels as reported by the Construction Industry Development Board (CIDB) Malaysia. CIDB identified that low 
productivity is linked to the limited implementation of new construction method and technologies, as well as high reliance on cheap labour and a mismatch of training and development for low skilled labour (CIDB, 2016). The continuous effort by the Central government and CIDB through new training programmes, new policies and various incentives showed little evidence of success. There is still a large gap between the availability of new technologies and the ability of the $\mathrm{Cl}$ to absorb, adopt and implement the new technologies. The main problem faced by the Malaysian $\mathrm{Cl}$ is not the shortage or non-availability of new construction method and advanced technologies, but the inability for the industry to absorb, use, benefit and implement the technologies throughout the whole lifecycle of the construction process.

Research in absorptive capacity have been widely conducted in various industries, such as in manufacturing (Duong 2020; Horvat et al., 2019); innovation and new product development (Liang et al., 2018; Strøm-Andersen, 2020); information technology and multimedia (Braojosa et al. 2020; van den Bosch et al., 1999), knowledge management and organisational learning (Liang et al., 2018; Ali et al., 2020). Research and studies mentioned above only focus on large organisations in high technology sectors with structured research and development (R\&D) plans, framework and/or strategies. According to Hirsch-Kreinsen et al. (2005), high technology sectors are those with high intensity in R\&D and with complex technology. Whereas medium and low technology sectors are those more mature industries with less or no investment in R\&D and not research-intensive.

Research into SME organisations focused on growth-orientated and high-technology organisations that consider R\&D activities as a core measurement of absorptive capacity. For example, recent study by Aboelmaged and Hashem (2019) reported that absorptive capacity plays an important role in influencing SME's sustainable capabilities and their innovation adoption. An earlier study by Liao et al. (2003) suggested that development of absorptive capacity on growth-orientated SMEs allows them to better appreciate, understand and evaluate environmental changes. SMEs with higher levels of absorptive capacity also tend to be more proactive and responsive to new challenges. Kodama (2008) suggested that a higher absorptive capacity of product-developing SMEs was linked to higher level of investment in R\&D. However, it is difficult to find small firms with necessary absorptive capacity, especially in rural 
regions. The findings by de Jong and Freel (2010) reflected that highly absorptive small organisations within the high technology industry were linked to high R\&D expenditures and were more likely to have innovation related collaboration with external organisations. In contrast, organisations in the low technology industry rarely conducted R\&D activities and their absorptive capacity was mainly developed from external push, which is market demand and customer requests (Ariana \& Asmara, 2018). Limaj and Bernroider (2019) reported that SMEs in knowledge-intensive industries created a strategic innovation mechanism to develop a higher level of absorptive capacity and accommodate balanced of organisational cultures.

Current research was from the SME low technology industries such as food and beverages industry, jewellery and design, and knowledge-intensive industries (Ariana \& Asmara, 2018). There were limited research measurements of how to identify and determine absorptive capacity outside the R\&D context for SME in mid-range technology industry, such as the $\mathrm{Cl}$. Thus, this research aims to identify absorptive capacity determinant criterion for SME construction organisations from a Malaysian context.

\section{Absorptive Capacity}

The concept of absorptive capacity originated from macroeconomics, where it referred to the ability of an economy to use its capital resources effectively (Adler, 1965). Throughout the years the concept of absorptive capacity has evolved, and it has been used in studies related to business administration and organisational learning. Cohen and Levinthal (1990) defined an organisation's absorptive capacity as its ability to recognise the value of new information, to assimilate that information and apply it to further its commercial ends, which led to extensive research work in many fields. Mowery and Oxley (1995) suggested that absorptive capacity is the ability to understand the external source of technology and apply it internally. They also suggested that in absorptive capacity, a broad set of skills is needed to deal with the tacit component of the transferred technology, as well as to cope with the necessity of transforming the imported technology for domestic application. Zahra and George (2002) described absorptive capacity in the form of four main processes by which organisations acquire, assimilate, transform and exploit knowledge to produce a 
dynamic organisational capability. Todorova and Durisin (2007) reintroduced the component of the absorptive capacity as recognition of the value of knowledge or technology, acquisition, transformation or assimilation, and exploitation. The transformation process is identified as the alternative process for the assimilation, not the process after the assimilation. Recognising the value of new knowledge and technology is the critical process before acquiring knowledge and can be described as the organisation's awareness in decisions to determine which technology will bring competitive advantage to the organisation. Ferreras-Méndez et al. (2015) later suggested that absorptive capacity served as a mediator in the relationship between the depth of external knowledge and the innovation and business performance of the firm. Findings show that the strength of effective absorptive capacity is higher, compared to effects of external partners. This indicated that external knowledge source may improve organisational innovation and performance when the learning process through absorptive capacity exists and is in order. Based on the various concepts of absorptive capacity, this research deduces that absorptive capacity is the 'ability to realise, acquire, learn, understand, and make use of new knowledge including new technologies to improve performance, which is also the fundamental requirement needed for the firm to innovate.

\section{Determinants of Absorptive Capacity}

Successful absorptive capacity in an organisation depends on various components and criteria. In an early study conducted by Cohen and Levinthal (1990), R\&D is one of the key factors in determining the absorptive capacity of organisations. Organisational knowledge transfer depended on R\&D activities with the availability of technology, investment and external information. This is further supported by Leahy and Neary (2007), whom suggested that R\&D activities increased organisational absorptive capacity as well as contributing directly to profitability. Schmidt (2010) argued that investment in R\&D alone was not sufficient for development of absorptive capacity; but suggested that continuous R\&D were significantly and positively related to organisational absorptive capacity.

Past research also reported that organisational absorptive capacity was determined by absorptive capacity of its individual members and their prior or related knowledge (Solnørdal \& Thyholdt, 2019; Limaj \& Bernroider, 2019). The breadth of prior 
knowledge will enhance individual learning: with more knowledge stored in the memory, the more readily an individual can establish linkages with new related knowledge and in turn acquire new knowledge (Bower \& Hilgard, 1981). A recent study by Liang et al. (2018) on Chinese organisations in manufacturing, telecommunication, metallurgy and petroleum industries in developed and underdeveloped regions in China, showed that team absorptive capacity contributed positively to team performance in new product development. These findings demonstrated that team learning is positively related to absorptive capacity.

Another absorptive capacity determinant is organisational structures and human resource management, which depended on the availability of the expertise and professional employees that can assimilate and transfer the knowledge (Adams et al., 2016; Santoro et al., 2020). Cohen \& Levinthal (1990) suggested organisations should have a 'gatekeeper' who is a specialised individual acting as the medium of communication between the organisation and the external environment, and interface between sub-units within the organisation. The main function of a 'gatekeeper' is to monitor the current trends and translate complex external knowledge into a format that is understandable by internal staff. Lichtenthaler (2016) argued that pro-active market orientation (knowledge) is an important component in developing organisation's absorptive capacity, with strong emphasis on new customers and good external knowledge acquisition.

Organisation absorptive capacity growth is also correlated with the level of knowledge and education of the employees. Schmidt (2010) found that employees with higher education and increased innovation activities were positively associated with high absorptive capacity. Ferreras-Méndez et al. (2015) reported that the availability of knowledge in the organisation affects performance and innovation levels in the organisation. Earlier research by Gray (2006) suggested that SME's owner(s) play an important role in developing its absorptive capacity. Owner(s) with higher education background and more experience in the industry tend to provide employees with wider range of development courses / training activities to develop employee's absorptive capacity. Literature review from previous research reported that high organisational absorptive capacity depended on both external and internal factors. Table 1 shows the key determinants and criterion measurement of organisational absorptive capacity. 
[insert Table 1]

\section{Research Methods}

This research utilises a combination of both deductive and inductive approaches to provide a balanced approach between theory and semi-structured interview analysis. Research started with a deductive approach using existing literature, reports and theory to identify issues related to the research; progressing into the inductive phase at the interview stage to better understand the process of absorptive capacity in construction SMEs and how organisations develop absorptive capacity. The next stage of the research involved semi-structured interviews, which include 12 construction SMEs operating in different States in Malaysia (Perlis, Kedah, Kelantan, Sarawak, Penang and Perak). The six different states were chosen as they represent the different areas and different levels of development in Malaysia. It is imperative for the research to ensure only construction SMEs were studied - and organisations were selected based on the operating locations, organisation registration with CIDB and their willingness to participate in the interviews. All the interviews were completed within the 6 months period. Malaysian CIDB categorisation of construction companies range from categories $\mathrm{G} 1$ to $\mathrm{G} 7$, which is based on organisational tendering capacity and paid-up capital. SMEs construction organisations fall under categories G3, G4 and G5 with organisational paid up capital not exceeding RM250,000 (approx. USD0.82 million), or tendering capacity not exceeding RM5 million (approx. USD1.65 million). Micro construction organisations fall under categories G1 and G2; and large construction organisations in G6 and G7 categories were not selected. G1 and G2 contractors were not selected due to the work undertaken was too small and not applicable for the study. Table 2 shows information of participating SMEs as case studies.

[insert Table 2]

The interviews involved top management (eg. Managing Director and Chief Executive Officer) on organisational policies and approach towards knowledge absorption. The questions were adapted from study by Kamal and Flanagan (2014) to suit the current research needs. The main questions addressed in the semi-structured interview were 
'how does your company develop the absorptive capacity?' and 'what effort did your company put to try to acquire, understand and use the new technology?'. The semistructured interview data was audio recorded and transcribed, then analysed using Nvivo 12 Pro software. Nvivo is a qualitative analysis software that allows researcher to sort, categorise and arrange unstructured data and to further examine the relationship of the data. Compared to other qualitative analysis software, Nvivo 12 Pro was chosen as best fit for the study as it allows easier data coding, more comprehensive data management and task analysis. The thematic approach was used to arrange and categorise the data. Two main themes were identified which include (1) absorptive capacity development practices; and (2) determinants of absorptive capacity. The main themes were then developed into nodes. Each of the factors identified in the transcribed interview were highlighted and coded into different nodes and placed into the related themes in Nvivo.

\section{Results:}

\section{A. Absorptive Capacity Development Practices by SMEs Construction Organisations}

The results of thematic analysis in Nvivo and the related nodes from the analysis are presented in Table 3. The results reported 29 main indicators of how construction SMEs developed their absorptive capacity. Based on the results, it is found that majority of the Malaysian construction SMEs rely on the training provided by CIDB as a mode to learn and explore new technology(ies) and process(es) and develop organisational absorptive capacity. It was mentioned 'to keep in pace with local construction trend, our company participated in Continuous Professional Development (CPD) courses and workshops held by CIDB. Due to the time and financial constraints, companies will only participate in the selected courses on topics based on individual interest or when courses are beneficial to the companies'. Most of the construction organisations also recommended that CIDB provide a mandatory training related to site safety.

[insert Table 3]

The results showed that suppliers and manufacturers were the main source for construction SMEs to develop absorptive capacity towards the new knowledge and 
technology. A participating organisation admitted that the organisation's efforts in training and using new technology was assisted by the information provided by suppliers, manufacturers, and consultants. In another scenario, suppliers required a two-pronged approach that addresses both the management and on-site application. First, for management level, suppliers need to market and demonstrate the product to the top management; secondly to conduct the demonstrations on application of the technology for workforce on-site to ensure the site workforce have better understanding on the technical aspect of the new technology. It is believed that onsite demonstrations were the best method to transfer the new knowledge to the workforce.

Owner(s) play a vital role in organisational absorptive capacity development processes through decision making processes, support in human resource management and strategic organisational communications - demonstrating that most information on new technology usually comes from the owners or directors of the organisation - which is echoed in the interviews. Owners also play a pivotal role in the organisation with full authority to take full charge of organisational operations, all stages of operational and decision-making processes. One of the contractors mentioned the top-level management supports the absorptive capacity process by providing training sessions to employees who were willing to learn and adapt to new knowledge and technology. For example, top-level management also allocated more resources to the technical department to ensure successful adoption of a new steel formwork system.'

Individual efforts to learn from the internet, books and magazines were also found as a common way to develop absorptive capacity. The interviews also found that competitions among construction organisations to secure work or projects have been the pushing factor to develop internal absorptive capacity.

\section{B. Determinants of Absorptive Capacity in SMEs Construction Organisations}

The interviews conducted informed that absorptive capacity in construction SMEs were very much influenced by its internal factors, which included the owner and employee(s). Results indicated that owners with higher education background with 
more experience in the industry tend to be more receptive towards new construction technology(ies), and acted as the catalyst for the organisation to adapt, absorb and implement the new technology(ies). For example, contractor B, G, H and I were led by owners with higher qualification (holder of a Bachelor's degree or higher from Higher Education Institutions) in the construction field with more than 15 years of experience in the industry, have successfully implemented state-of-the art concrete pumping technology, solar roofing system, industrialised building systems (IBS) and glass fibre reinforced concrete in respective organisations. The interviews also indicated that owners understood the benefits of technology(ies) for their projects and were more receptive to innovative ideas. In addition, more experienced owners had time to build better relationships and reputation with the client to allow absorption of new construction technologies. Human resource management and formal office communication were also a determinant criterion. Participants in the interviews agreed that having employees with high levels of knowledge implies a higher capital investment in human resources by the organisation; in return the absorptive capacity of the employee is usually higher. According to the contractors, if the human resources development were improved through the support of top management, employees will be more motivated, and the process of knowledge transfer will also be more successful. Rising human capital development will enhance the employees' learning and increase speed of absorbing new technology. Figure 1 shows the related nodes on the determinants of absorptive capacity in Malaysian construction SMEs.

\section{[insert Figure 1]}

In relation to employee criteria as determinants of absorptive capacity, the interviews found five employee related factors - motivation, past experience, education background, involvement, and skills. This is supported by a contractor who mentioned the background of employees played an important role in absorptive capacity development process in the organisation. Employees with higher education background require a shorter time to understand and absorb new knowledge compared to other colleagues. In relation to employee's involvement, a contractor mentioned the involvement of the employees in the absorptive capacity is the key element to ensure the success of the absorptive capacity process, as they are the people who learned and would apply the new knowledge and technology in the 
construction activity'.

Contractors $\mathrm{J}, \mathrm{K}$ and $\mathrm{L}$ agreed that involvement of employees to improve their knowledge and gain more information about the implementation of IBS technology on site has brought significant benefit to the organisation, as the employee increased their skills through experience. At the same time, the interviews conducted found that motivated employees have a positive impact on organisational absorptive capacity process, in which motivated employees were more willing to fully commit in attending the training or courses organised by the organisation about new technology and knowledge.

The interviews also found another external factor, whereby suppliers and manufacturers, appeared to be an important determinant of absorptive capacity for construction organisations. A close working relationship between the contractors and suppliers/manufacturers have assisted organisations in gaining new knowledge and technology to be implemented on site. Most contractors rely on the suppliers/manufacturers to improve their knowledge on the new technology. Their decision making on the application of new technology on site would depend on the cost and quality of the materials. According to a contractor, selecting the best possible supplier is important as suppliers were the source of new knowledge to the contractors.

\section{Discussion}

The semi-structured interviews conducted provided a clear understanding of the Malaysian construction SMEs capability to absorb new knowledge and technology, and the main determinants of organisational absorptive capacity. Through the interviews, it is found that the determinants of contractor's absorptive capacity were very much influenced by their organisational characteristics (SME characteristics). As discussed by Kamal and Flanagan (2014), one of the main characteristics was the owner of the organisation, who have a dominant role in decision making processes and with hands-on approach to the operations of the organisation. In this study, it is found that owners with higher education level and experience in the industry have more positive impact on organisational absorptive capacity. This finding corresponds with the recent study by Zor et al. (2019), in which it was reported that the Chief 
Executive's education level in SMEs firms and their degree of openness to experience are closely correlated towards favourable budget considerations in the organisation. The findings also correspond to study by Schmidt (2010) mentioned earlier. The findings illustrated that the SME leaders also customise organisational practices toward their personal characteristics. The results from the interviews also echo with the earlier findings by Gray (2006) who suggested that owner of SMEs firms plays an important role in the firm's absorptive capacity process.

Compared to large organisations with strong capability to invest in R\&D activities and having a 'gatekeeper' as medium of communication between organisation and external environment as mentioned by Cohen \& Levinthal (1990): this does not happen in construction SMEs. However, the findings suggested that having an experienced employee with higher education background and better skills has increased the organisation's ability to absorb new technology. This criterion is also linked to employees prior related knowledge that have a positive impact on organisation and individual absorptive capacity as been revealed by Solnørdal et al. (2019), and much earlier study by Bower \& Hilgard (1981). The findings of the study reflect study by Lin (2011) who surveyed on 243 senior executives from large organisation in Taiwan found that employee's motivation is closely related to knowledge management implementation. The interviews conducted further identify that employee involvement in the process of acquiring the new knowledge, learning about the new technology also has a positive impact on SMEs absorptive capacity. Prokop and Stejskal (2019) suggested that small enterprises should primarily focus on the activities and expenditures for product and process innovation specifically in-house R\&D, acquisition of machinery, equipment, software and buildings. Their study also found that training for innovative activities for medium sized enterprises are the most important determinants of product and process innovation activities.

Comparing the results with the study by Ariana \& Asmara (2018), who researched in low technology industries in Indonesia, there were resemblance with Malaysian construction SMEs. Although $\mathrm{Cl}$ is not considered as a low-tech industry, construction SMEs very much rely on external source (eg. suppliers/manufacturer) and training provided by regulative bodies (eg. CIDB) as their platform to learn new knowledge and technology, and as a driver towards innovation. The resemblance of the results is 
suspected to be related to the characteristics of the SMEs that having a limited staff and limited capital to develop their own internal capabilities. Interestingly, the findings also demonstrated that construction SMEs in the same industry regard competitor SMEs as a source of new knowledge and absorptive capacity. Success stories from other competitors in implementing new construction technology has inspired SMEs to further learn, absorb and apply the same technology.

\section{Conclusion}

The SME construction organisations play a vital role in the Malaysian economy by contributing towards the national GDP and employment. However, the productivity levels have been a constant issue in the past decade. The problems with productivity and performance has a huge impact on the ability of the $\mathrm{Cl}$ to be more efficient, to provide safer workspace and deliver high-quality construction. There is an urgent need for the SMEs to absorb the new knowledge and make greater use of new technologies available in the market to improve their productivity levels.

The study demonstrated an understanding on absorptive capacity development practices in SME construction organisations and the factors that determined their absorptive capacity. A list of 29 main indicators on how construction SMEs developed its absorptive capacity were identified; and 10 factors were identified as important determinants of organisation absorptive capacity.

The findings of this study contributed to the domain of study related to Malaysian construction SMEs absorptive capacity. The geographical limitation of the case studies on Malaysian contractors does not constraint their generalizability to other developing nations in southeast Asia and other regions. This research provides a clear indication of the criteria in determining absorptive capacity in the organisation SMEs that can further developed, to include other methodological approaches, such as the readiness of construction SMEs, as discussed by Lou et al. (2020). The findings from this research also will benefit the construction SMEs as it provides highlights on key areas for organisations to further improve, to increase their performance and productivity. Whilst this research focuses on Malaysian SMEs construction organisations, future research may consider further investigation on the impact of personal characteristics of SME's owners and employees to their ability to absorb and 
implement new knowledge and technologies.

\section{Acknowledgements}

This research was funded and supported by Universiti Sains Malaysia (Grant No: 304/PPBGN/6312138).

\section{References}

Aboelmaged, M. \& Hashem, G. (2019). Absorptive capacity and green innovation adoption in SMEs: The mediating effects of sustainable organisational capabilities. Journal of Cleaner Production, 220, 853-863.

Adams, D.R., Flatten, T.C., Brinkmann, H. \& Brettel, M. (2016). Consequences and antecedents of absorptive capacity in a cross-cultural context. International Journal of Innovation Management, 20(1), 1650003.

Adler, J.H. (1965). Absorptive Capacity: The Concept and Its Determinants. Washington D.C: The Brookings Institute.

Ali, A., Bahadur, W., Wang, N., Luqman, A. \& Khan, A.N. (2020). Improving team innovation performance: Role of social media and team knowledge management capabilities. Technology in Society, 61, 101259.

Ariana, L. \& Asmara, I.J. (2018). Absorptive capacity in low-tech industry: Case Study of Indonesian Manufacturing Companies. 2nd International Conference on Technology, Innovation, Society and Science-to-Business, ICTIS 2018.

BNM. (2020). Economic and Monetary Review 2019. Bank Negara Malaysia. https://www.bnm.gov.my/ar2019/files/emr2019 en full.pdf [Date accessed 16 June 2020].

Bower, G.H. \& Hilgard, E.R. (1981). Theories of Learning. 5th Edition. New Jersey: Prentice-Hall.

Braojosa, J., Benitez, J., Llorens, J. \& Ruiz, L. (2020). Impact of IT integration on the firm's knowledge absorption and desorption. Information \& Management, 103290.

Cepeda-Carrion, G., Cegarra-Navarro, J.G. \& Jimenez-Jimenez, D. (2012). The effect of absorptive capacity on innovativeness: Context and information systems capability as catalysts. British Journal of Management, 23(1), 110-129. 
CIDB. (2016). Construction Industry Transformation Programme 2016-2020. Construction Industry Development Board (CIDB), Kuala Lumpur. http://www.citp.my/ [Date accessed 15 June 2020].

Cohen, W.M. \& Levinthal, D.A. (1990). Absorptive Capacity: A New Perspective on Learning and Innovation. Administrative Science Quarterly, 35, 128-152.

de Jong, J.P.J. \& Freel, M. (2010). Absorptive capacity and the reach of collaboration in high technology small firms. Research Policy, 39, 47-54.

DoSM. (2020). Small and Medium Enterprises (SMEs) Performance 2018. Department of Statistics Malaysia (DoSM). https://www.dosm.gov.my/v1/index.php?r=column/cthemeByCat\&cat=159\&bul id=R0Vka2RpeVJ0cUlpR3BqdjhudDZhdz09\&menu id=TE5CRUZCblh4ZTZM ODZlbmk2aWRRQT09 [Date accessed 15 June 2020].

Duong, W.H. (2020). The threshold of absorptive capacity: The case of Vietnamese manufacturing firms. International Economics, 163, 44-57.

Evans, N. \& Bosua, R. (2014). Knowledge absorption in organisations Development of a conceptual process model. Proceedings of the 15th European Conference on Knowledge Management, Santarém, Portugal.

Ferreras-Méndez, J.L., Newell, S., Fernández-Mesa, A. \& Alegre, J. (2015). Depth and breadth of external knowledge search and performance: The mediating role of absorptive capacity. Industrial Marketing Management, 47, 86-97.

Flatten, T., Adams, D. \& Brettel, M. (2015). Fostering absorptive capacity through leadership: A cross-cultural analysis. Journal of World Business, 50(3), 519534.

Foss, N.J., Lyngsie, J. \& Zahra, S.A. (2013). The role of external knowledge sources and organizational design in the process of opportunity exploitation. Strategic Management Journal, 34(12), 1453-1471.

Gray, C. (2006). Absorptive Capacity, knowledge management and innovation in entrepreneurial small firms. Journal of Entrepreneurial Behaviour \& Research, 12(6), 345-360.

Hirsch-Kreinsen, H., Jacobson, D. \& Robertson, P. (2005). "Low-Tech" Industries: Innovativeness and Development Perspectives - A Summary of a European Research Project", Prometheus, 24(1), 3-21. 
Horvat, D., Dreher, C. \& Som, O. (2019). How firms absorb external knowledgemodelling and managing the absorptive capacity process. International Journal of Innovation Management, 23(1), 1950041.

Kamal, E.M. \& Flanagan, R. (2014). Key Characteristics of Rural Construction SMEs. Journal of Construction in Developing Countries, 19(2), 1-13.

Kodama, T. (2008). The role of intermediation and absorptive capacity in facilitating university-industry linkages_-An empirical study of TAMA in Japan. Research Policy, 37, 1224-1240.

Lane, P.J. \& Lubatkin, M. (1998). Relative absorptive capacity and interorganizational learning. Strategic Management Journal, 19, 461-477.

Leahy, D. \& Neary, J.P. (2007). Absorptive capacity, R\&D spillovers, and Public Policy. International Journal of Industrial Organization, 25(5), 1089-1108.

Liang, H., Sun, W., Fonseka, M.M. \& Zhou, F. (2018). Goal orientations, absorptive capacity, and NPD team performance: evidence from China. Chinese Management Studies, 13(2), 489-510.

Liao, J., Welsch, H. \& Stoica, M. (2003). Organizational Absorptive Capacity and Responsiveness: An Empirical Investigation of Growth-Oriented SMEs. Entrepreneurship Theory and Practice, Fall, 63-86.

Lichtenthaler, U. (2016). Determinants of absorptive capacity: the value of technology and market orientation for external knowledge acquisition. Journal of Business and Industrial Marketing, 31(5), 600-610.

Limaj, E. \& Bernroider, E.W.N. (2019). The roles of absorptive capacity and cultural balance for exploratory and exploitative innovation in SMEs. Journal of Business Research, 94, 137-153.

Lin, C., Tan, B. \& Chang, S. (2002). The Critical Factors for Technology Absorptive Capacity. Industrial Management and Data Systems, 102(6), 300-308.

Lin, H.F. (2011). The effects of employee motivation, social interaction, and knowledge management strategy on KM implementation level. Knowledge Management Research and Practice, 9(3), 263-275.

Lou, E.C.W., Lee, A. \& Goulding, J.S. (2020). E-Readiness in Construction (ERiC): Self-Assessment Framework for UK Small and Medium Enterprise Building Service Providers. Architectural Engineering and Design Management, 15(1), 3-22. 
Mowery, D.C. \& Oxley, J.E. (1995). Inward Technology Transfer and Competitiveness: The Role of National Innovation Systems. Cambridge Journal of Economics, 19, 67-93.

Prokop, V. \& Stejskal, J. (2019). Determinants of Innovation Activities and SME Absorption - Case Study of Germany. Scientific papers of the University of Pardubice, Series D, 46.

Rezaei-Zadeh, M. \& Darwish, T.K. (2016). Antecedents of absorptive capacity: a new model for developing learning processes. Learning Organization, 23(1), $77-91$.

Santoro, G., Bresciani, S. \& Papa, A. (2020). Collaborative modes with Cultural and Creative Industries and innovation performance: The moderating role of heterogeneous sources of knowledge and absorptive capacity. Technovation, 92-93, 102040.

Schmidt, T. (2010). Absorptive Capacity. One Size Fits All? A Firm-level Analysis of Absorptive Capacity for Different Kinds of Knowledge. Managerial and Decision Economics, 31, 1-18.

SMECorp. (2020). Here's why SMEs matter in Malaysia. SME Corp Malaysia (SMECorp). https://www.smeinfo.com.my/profile-of-smes [Date accessed 15 June 2020].

Solnordal, M.T. \& Thyholdt, S.B. (2019). Absorptive capacity and energy efficiency in manufacturing firms - An empirical analysis in Norway. Energy Policy, 132, 978-990.

Strom-Andersen, N. (2020). Production Innovation and by-product valorization: A comparative analysis of the absorptive capacity of food processing firms. Journal of Cleaner Production, 253, 119943.

Todorova, G. \& Durisin, B. (2007). Absorptive capacity: Valuing a reconceptualization. Academy of Management Review, 32(3), 774-786.

Van den Bosch, F.A., Volberda, H.W. \& de Boer, M. (1999). Coevolution of firm absorptive capacity and knowledge environment: Organizational forms and combinative capabilities. Organization science, 10(5), 551-568.

Zahra, S.A. \& George, G. (2002). Absorptive Capacity: A Review, Reconceptualization, and Extension. Academy of Management Review, 27(2), 185-203. 
Zerwas, D. (2014). Organizational culture and absorptive capacity: The meaning for SMEs. Koblenz-Landau: Springer Gabler.

Zor, U., Linder, S. \& Endenich, C. (2019). CEO Characteristics and Budgeting Practices in Emerging Market SMEs. Journal of Small Business Management, $57(2), 658-678$.

Table 1: Key determinants and measurement criteria of organisational absorptive capacity

\begin{tabular}{|c|c|c|}
\hline $\begin{array}{c}\text { Key } \\
\text { Determinant }\end{array}$ & $\begin{array}{c}\text { Measurement } \\
\text { Criteria }\end{array}$ & References \\
\hline R\&D & $\begin{array}{l}\text { - Investment } \\
\text { - Continuous activities }\end{array}$ & $\begin{array}{l}\text { - Cohen \& Levinthal (1990) } \\
\text { - Leahy \& Neary (2007) } \\
\text { - Schmidt (2010) }\end{array}$ \\
\hline Organisational & $\begin{array}{l}\text { - Organisational structure / design } \\
\text { - Leadership style } \\
\text { - Cooperative culture } \\
\text { - Open communication } \\
\text { - Collective reward } \\
\text { - Organisational culture }\end{array}$ & $\begin{array}{l}\text { - Adams et al. (2016) } \\
\text { - Santoro et al. (2020) } \\
\text { - Flatten et al. (2015) } \\
\text { - Foss et al. (2013) } \\
\text { - Lane \& Lubatkin (1998) } \\
\text { - Limaj \& Bernroider (2019) } \\
\text { - van Den Bosch et al. (1999) } \\
\text { - Welsch et al. (2001) } \\
\text { - Zerwas (2014) }\end{array}$ \\
\hline $\begin{array}{l}\text { Individual } \\
\text { (employees) }\end{array}$ & $\begin{array}{l}\text { - Prior related knowledge } \\
\text { - Organisational structure } \\
\text { - Human resource management } \\
\text { - Learning capabilities } \\
\text { - Learning process } \\
\text { - Team learning } \\
\text { - Expertise and professional } \\
\text { employee } \\
\text { - Employee motivation } \\
\text { - Employee education } \\
\text { - Owner's education }\end{array}$ & $\begin{array}{l}\text { - Bower \& Hilgard (1981) } \\
\text { - Solnørdal \& Thyholdt (2019) } \\
\text { - Limaj \& Bernroider (2019) } \\
\text { - Cohen \& Levinthal (1990) } \\
\text { - Ferreras-Méndez et al. (2015) } \\
\text { - Gray (2006) } \\
\text { - Koskinen \& Vanharanta (2002) } \\
\text { - Liang et al. (2018) } \\
\text { - Lichtenthaler (2016) } \\
\text { - Lin (2011) } \\
\text { - Schmidt (2010) } \\
\text { - Rezaei-Zadeh \& Darwish (2016) }\end{array}$ \\
\hline $\begin{array}{l}\text { Other } \\
\text { determinants }\end{array}$ & $\begin{array}{l}\text { - Information system capabilities } \\
\text { - Internal and external social } \\
\text { networks } \\
\text { - Market demand } \\
\text { - Customer }\end{array}$ & $\begin{array}{l}\text { - Ariana \& Asmara (2018) } \\
\text { - Cepeda-Carrion et al. (2012) } \\
\text { - Evans \& Bosua (2014) } \\
\text { - Lane \& Lubatkin (1998) } \\
\text { - Lin (2011) }\end{array}$ \\
\hline
\end{tabular}


Table 2: Information on participating SME construction organisations

\begin{tabular}{|c|c|c|c|c|c|}
\hline Organisation & Category & Location & $\begin{array}{c}\text { Year } \\
\text { Established }\end{array}$ & $\begin{array}{c}\text { Main } \\
\text { Client(s) }\end{array}$ & $\begin{array}{c}\text { No. of } \\
\text { Employees }\end{array}$ \\
\hline A & G5 & Sarawak & 2008 & $\begin{array}{c}\text { Public / } \\
\text { Government }\end{array}$ & 12 \\
\hline B & G5 & Sarawak & 1987 & Private & 24 \\
\hline C & G5 & Perlis & 2007 & $\begin{array}{c}\text { Public / } \\
\text { Government }\end{array}$ & 14 \\
\hline D & G3 & Kedah & 2006 & Private & 10 \\
\hline E & G4 & Kelantan & 2000 & $\begin{array}{c}\text { Public / } \\
\text { Government }\end{array}$ & 8 \\
\hline F & G5 & Penang & 2005 & Private & 30 \\
\hline G & G4 & Perak & 2005 & Private & 22 \\
\hline H & G5 & Penang & 2004 & $\begin{array}{c}\text { Public / } \\
\text { Government }\end{array}$ & 13 \\
\hline I & G3 & Penang & 2010 & Private & 5 \\
\hline J & G4 & Penang & 2010 & Private & 25 \\
\hline K & G5 & Penang & 1992 & Private & 46 \\
\hline L & G5 & Penang & 2010 & Private & 34 \\
\hline
\end{tabular}

Table 3: Absorptive capacity development practices by SMEs Construction Organisations

\begin{tabular}{|c|c|c|c|c|c|c|c|c|c|c|c|c|}
\hline \multirow[t]{2}{*}{ Absorptive Capacity Development Practices } & \multicolumn{12}{|c|}{ Construction Organisation } \\
\hline & A & B & $\mathrm{C}$ & $\mathrm{D}$ & $\mathrm{E}$ & $\mathrm{F}$ & G & $\mathrm{H}$ & I & $\mathrm{J}$ & $K$ & $\mathrm{~L}$ \\
\hline Books / Magazine & $\mathrm{x}$ & $\mathrm{x}$ & $\mathrm{x}$ & $\mathrm{x}$ & $x$ & & & & & & & \\
\hline Client & & & & & & & & $x$ & & $x$ & $x$ & \\
\hline Competitor & & & & & & & & & & $\mathrm{x}$ & $x$ & $\mathrm{x}$ \\
\hline Consultant & & & & & & & & $x$ & $x$ & $x$ & & \\
\hline Employee's education background & & & & & & & & & & & & $\mathrm{x}$ \\
\hline Employee's involvement & & & & & & & & & & $x$ & $x$ & $\mathrm{x}$ \\
\hline Employee's motivation & & & & & & & & & & $\mathrm{x}$ & $x$ & $\mathrm{x}$ \\
\hline Employee's past experienced & & & & & & & & & $x$ & & & $\mathrm{x}$ \\
\hline Employee's skills & & & & & & & & & & $x$ & & \\
\hline Exhibition & & & & & & & & & $x$ & & & \\
\hline Human Resource Management & & & & & & & & $x$ & & $\mathrm{x}$ & $x$ & $x$ \\
\hline Initiatives by the Government & & & & & & & $x$ & & & & & \\
\hline Internet (Website) & $x$ & $x$ & $x$ & $x$ & $x$ & & & & & & & \\
\hline Join-venture with other organisations & & & & & & & & $x$ & & $\mathrm{x}$ & & \\
\hline Leadership style & & & & & & & & & & $\mathrm{x}$ & $x$ & $x$ \\
\hline Learning by doing & & & & & & $x$ & & & & & & \\
\hline Market demand & & & & & & & & & & $x$ & & \\
\hline Office formal communication & $x$ & $\mathrm{x}$ & $x$ & $x$ & $x$ & & & & & & & \\
\hline Organisation structure & & & & & & & & $x$ & & & & \\
\hline Own initiatives & & $x$ & & & $x$ & & & & & & & \\
\hline
\end{tabular}




\begin{tabular}{|c|c|c|c|c|c|c|c|c|c|c|c|c|}
\hline Owner of the organisation & $\mathrm{x}$ & $\mathrm{x}$ & $\mathrm{x}$ & $\mathrm{x}$ & $\mathrm{x}$ & & & & & & $\mathrm{x}$ & \\
\hline Owner's education background & $\mathrm{x}$ & $\mathrm{x}$ & $\mathrm{x}$ & & & & $\mathrm{x}$ & & $\mathrm{x}$ & & & \\
\hline Owner's experience in the industry & & $\mathrm{x}$ & & & & & $x$ & $\mathrm{x}$ & $\mathrm{x}$ & & & \\
\hline Superiors and work colleagues & & & & $x$ & $x$ & $x$ & & $x$ & & $\mathrm{x}$ & & \\
\hline Suppliers and manufacturers & & $\mathrm{x}$ & & & & $\mathrm{x}$ & & $\mathrm{x}$ & $x$ & $x$ & $\mathrm{x}$ & \\
\hline Teamwork & & & & & & & & & & & $\mathrm{x}$ & \\
\hline Training by CIDB & $\mathrm{x}$ & & $\mathrm{x}$ & $\mathrm{x}$ & $x$ & $\mathrm{x}$ & $x$ & $x$ & $x$ & & & \\
\hline Training by other external parties & & & & & & $x$ & & & & & & \\
\hline Training by the organisation (internal) & $\mathrm{x}$ & & $\mathrm{x}$ & $\mathrm{x}$ & & & & & & $x$ & & $x$ \\
\hline
\end{tabular}

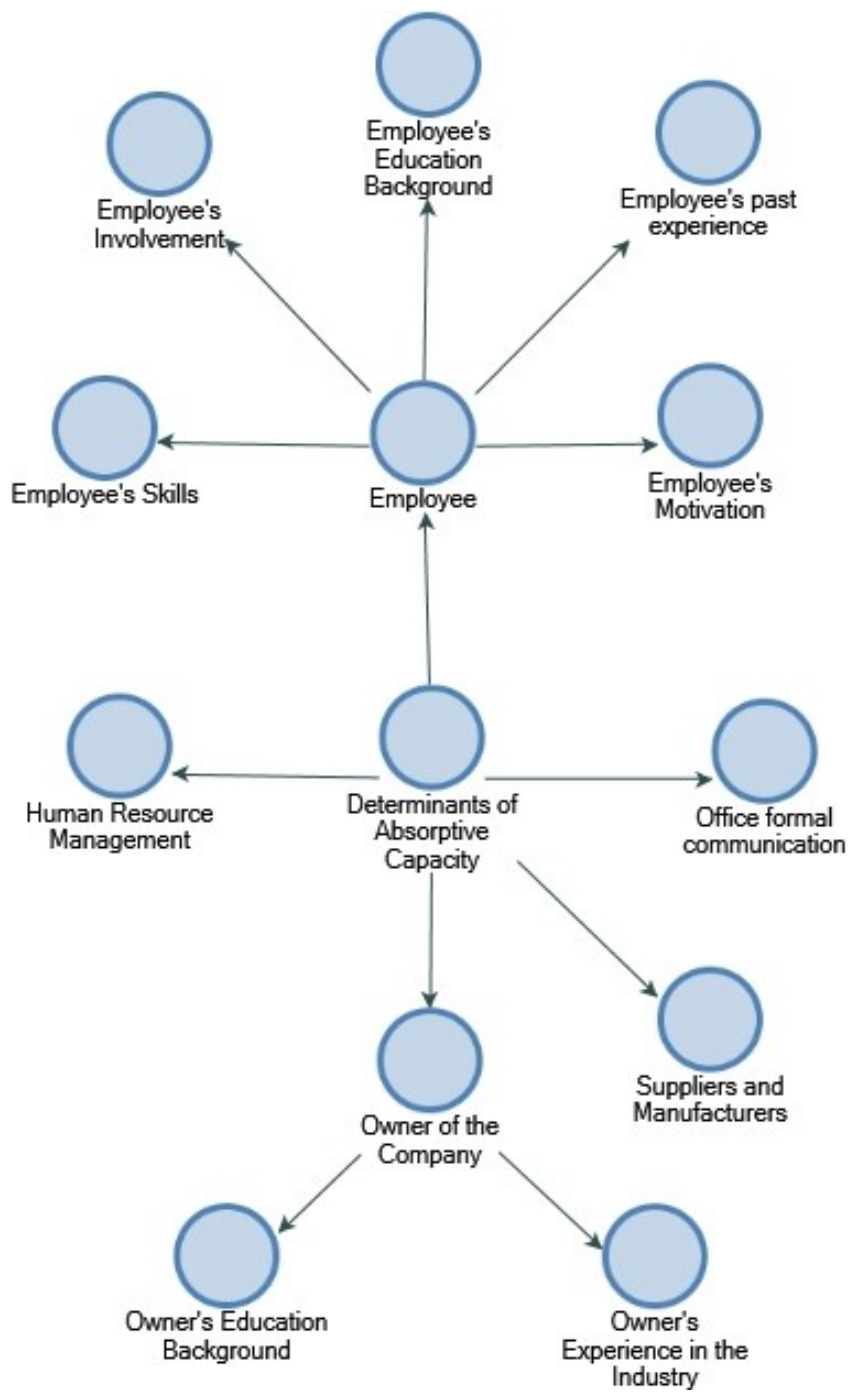

Figure 1: Determinants of absorptive capacity in SMEs construction organisations 